\title{
DE MÃOS VAZIAS: SETE CANTOS DO POETA PARA O ANJO, DE HILDA HILST
}

With empty hands: Sete cantos do poeta para o anjo, by Hilda Hilst

\author{
Enivalda Nunes Freitas e SOUZA ${ }^{13}$ \\ UFU \\ enivaldanf@gmail.com
}

Karyne Pimenta de Moura COSTA ${ }^{14}$

PMU

karynepdm@yahoo.com.br

RESUMO: Este artigo analisa a obra Sete cantos do poeta para o anjo (1962), de Hilda Hilst, a partir do prefácio assinado por Dora Ferreira da Silva, "Duas experiências do angélico". O fio condutor se amarra à leitura da prefaciadora que defende um anjo solarizado, ainda que quase sempre ausente e sempre de mãos vazias, daí seu hibridismo. Os cantos são de tonalidade metalinguística, metafísica e social. Para a compreensão desse Anjo ambíguo, que tanto oferta promessas quanto oferece dor, morte, noite e sacrifícios, recorre-se às Elegias de Duíno, de Rainer Maria Rilke, poeta que figura nas leituras de Hilda Hilst, traduzido dez anos depois por Dora Ferreira da Silva.

Palavras-chave: Hilda Hilst. Dora Ferreira da Silva. Anjo. Poesia. Metalinguagem.

ABSTRACT: This article analyses the book of poems Sete cantos do poeta para o anjo (1962), by Hilda Hilst, as from the preface signed by Dora Ferreira da Silva, "Two experiences of the angelical". The common thread is tied at the

${ }^{13}$ Professora titular no Instituto de Letras e Linguística da Universidade Federal de Uberlândia (UFU). Pós-Doutora em Estudos Literários pela Universidade Federal de Minas Gerais (UFMG).

${ }^{14}$ Professora de Literatura pela Prefeitura Municipal de Uberlândia (PMU). Mestra em Teoria Literária e doutoranda em Estudos Literários pela Universidade Federal de Uberlândia (UFU).

Revista TextoPoético | ISSN: 1808-5385 | Vol. 21 (2o sem-2016) - p. 57. 
reading made by Dora Ferreira da Silva, who speaks up for the solarized angel, almost ever absent and always with empty hands, and that is where its hybridism comes from. The cantos have metalinguistic, metaphysics and social tone. To understand this ambiguous Angel, that offers as much as promises pain, death, night and sacrifices, it is necessary to have recourse to the Duino Elegies, by Rainer Maria Rilke, poet who is portrayed at Hilda Hilst's readings and that would be translated ten years later by Dora Ferreira da Silva.

Keywords: Hilda Hilst. Dora Ferreira da Silva. Angel. Poetry. Meta-language.

\section{Hilda e Dora}

Em 1962, Hilda Hilst publica Sete cantos do poeta para o anjo $^{15}$, um trabalho que se completa com a primorosa ilustração de Wesley Duke Lee, importante artista plástico nascido na cidade de São Paulo (SP) e de grande repercussão já nos anos de 1960. Outro aspecto importante desse livro, que arrebataria o Prêmio PEN Clube de São Paulo, ainda em 1962, é o prefácio da poeta Dora Ferreira da Silva (Conchas, SP, 1918; São Paulo, 2006), "Duas experiências do angélico", texto praticamente esquecido pela crítica, mas iluminador da poesia de Hilst.

Para a melhor compreensão do prefácio à obra de Hilda Hilst, algumas informações sobre Dora Ferreira da Silva são importantes. Dora só publicaria seu primeiro livro oito anos depois, em 1970, enquanto Hilda Hilst já gozava de uma certa reputação e Wesley Duque Lee era um artista de vulto que promovia happenings na cidade de São Paulo. Por sua vez, o nome de Dora também circulava pela capital paulista, cuja residência fora transformada numa casa de fomento às atividades do espírito, como palestras, leituras poéticas,

${ }^{15}$ A versão original da obra é intitulada Sete cantos do poeta, para o anjo. Todavia, seguiremos a edição da Editora Globo, cujo título não apresenta vírgula.

Revista TextoPoético | ISSN: 1808-5385 | Vol. 21 (2o sem-2016) - p. 58. 
reflexões religiosas e filosóficas - a Casa do Espírito, conforme a nomeou Guimarães Rosa em carta ao casal Ferreira da Silva. A revista Diálogo (1955-1963), coordenada pelo esposo de Dora, o filósofo Vicente Ferreira da Silva, era o que havia de mais consistente em termos de divulgação do pensamento brasileiro naqueles anos. Após o falecimento do esposo, Dora cria com amigos a revista Cavalo Azul (1964-1989), privilegiando as artes e a literatura. Além de poeta e tradutora, Dora ministrou cursos sobre Carl Gustav Jung e foi conferencista. Conforme depoimento de Cláudio Willer, no texto "Encarnações da poesia":

São Paulo, em 1960, sendo já uma metrópole, ainda tinha, culturalmente, caracteristicas de província. Sabia-se de tudo, ou do que importava, sem precisar de noticiário na imprensa. Um dos assuntos da cidade naquele momento: a palestra sobre Artaud por Dora Ferreira da Silva (WILLER, 2006).

No mesmo depoimento, Cláudio Willer registra as habilidades da conferencista na Biblioteca Mário de Andrade ao "incorporar" Artaud e trazer Hölderlin para questões da atualidade:

O que se comentava: em vez de limitar-se a expor, a falar sobre o criador do teatro da crueldade, ela o havia encarnado de um modo que espantou a plateia. Deu palestra sobre Saint-John Perse em um ciclo sobre a poesia e o mar, que organizei em 1998 na Biblioteca Mário de Andrade. Foi a conferencista sobre Hölderlin em outro ciclo na mesma biblioteca, em 1999, sobre poetas rebeldes e malditos. Politizou Hölderlin, perguntando que respostas ele ofereceria para o mundo dessacralizado de hoje, o mundo do qual os deuses se retiraram. Auditório lotado, uma hora de palestra, prolongados aplausos em pé ao final (WILLER, 2006).

Revista TextoPoético | ISSN: 1808-5385 | Vol. 21 (2o sem-2016) - p. 59. 
As aproximações entre Dora Ferreira da Silva e Hilda Hilst começam pela vida social de cada uma, no que concerne à retirada de Hilst das badalações de São Paulo e da reclusão igualmente voluntária de Dora. No seio de suas próprias residências, ambas prezavam a troca de experiências literárias e artísticas, o permanente cultivo da inteligência e da sensibilidade. Dora Ferreira da Silva em sua casa - a Casa do Espírito - na Rua José Clemente, em São Paulo; Hilda Hilst na Casa do Sol, em Campinas, SP. Por outro lado, os poetas que Hilst amou, segundo a lista de Anatol Rosenfeld, também foram amados por Dora e traduzidos por ela, como Hölderlin, Rainer Maria Rilke, John Donne, Eliot e Saint-John Perse.

Para o desenvolvimento da reflexão que ora se apresenta, partiremos das pontuações de Dora Ferreira da Silva no Prefácio e da análise dos Sete cantos do poeta para o anjo, em que se podem entrever temas definitivos em Hilda Hilst (e em Dora), como o mergulho nos extratos profundos do inconsciente, a transfiguração sofrida da linguagem, a unidade da vida e da morte e a forçosa ambivalência do poeta entre o que percebe e o que consegue realizar. Na junção desses opostos, delineia-se a imagem do Anjo ambíguo, nem puro nem impuro, que salta como imagem da poesia e força imanente do poeta. Ressalte-se, contudo, que a investigação desse estudo recai tão-somente sobre a referida obra de Hilda Hilst; não se trata, portanto, de um estudo comparativo entre as duas poetas.

\section{Um prefácio e dois anjos}

No prefácio aos Sete cantos do poeta para o anjo, "Duas experiências do angélico", Dora Ferreira da Silva (1962) percebe um anjo conciliador de opostos de cuja presença luminosa não se

Revista TextoPoético | ISSN: 1808-5385 | Vol. 21 (2o sem-2016) - p. 60. 
pode esperar muito: escreve que Hilst canta para seu "anjo imanente" as "sete cores do arco-íris, do arco da aliança", em uma poesia límpida, mas vigorosa, que anuncia "sem tumultos ou grandes exaltações" um Anjo de "asas de arco-íris e mãos nuas". De um lado, um ser refulgente, todo plenitude; de outro, as mãos vazias, que nada oferecem. A tensão permanece até o último canto: "o sétimo, é o círculo que se fecha, numa súbita reminiscência de noite e de dor, treva e fragilidade, para enfim resplandecer o Anjo como 'prisma solarizado / transcendência primeira / dulcíssima presença" (SILVA, 1962).

Profunda conhecedora das representações estéticas do imaginário, amiga da pintora Yolanda Mohally, Dora observa uma "anteposição poética" nos desenhos de Wesley Duke Lee ao livro de Hilda Hilst, desaprovando a insistência do artista na representação de um Anjo de perfil negativo. Dora acredita que ilustrador e poeta falam de "Duas experiências do angélico": o anjo de Hilst é um "Anjo solar, arquetipicamente vindo do Alto", ao passo que os anjos de Duke Lee são "anjos-íncubos", "assimétricos e incompletos que realizam uma experiência negra do angélico, nada que se aproxime daquela conciliação dos opostos dos Setes cantos do poeta para o anjo". E sentencia: "estamos em presença de duas realizações artísticas incomunicantes" (SILVA, 1962, grifo nosso). Contudo, considera essa diversidade como expressão da riqueza "dos caminhos imanentes destes dois poetas", atribuindo o epíteto de poeta ao artista plástico.

As ilustrações de Wesley Duke Lee podem ter sido inspiradas no Angelus Novus, de Paul Klee, desenho feito em 1920, do qual fala Walter Benjamin na "nona tese", mostrando-o como anjo mensageiro da morte, descrente do passado e sem esperança no futuro:

Revista TextoPoético | ISSN: 1808-5385 | Vol. 21 (2o sem-2016) - p. 61. 
Seu rosto está dirigido para o passado. Onde nós vemos uma cadeia de acontecimentos, ele vê uma catástrofe única, que acumula incansavelmente ruina sobre ruína e as dispersa a nossos pés. Ele gostaria de deter-se para acordar os mortos e juntar os fragmentos. Mas uma tempestade sopra do paraíso e prende-se em suas asas com tanta força que ele não pode mais fechá-las. Essa tempestade o impele irresistivelmente para o futuro, ao qual ele vira as costas, enquanto o amontoado de ruínas cresce até o céu (BENJAMIN, 1985, p. 226).

Ainda que queira "acordar os mortos e juntar os fragmentos", o anjo mensageiro de Walter Benjamin "aparece como figura de uma efemeridade ameaçadora, por abrigar em si um forte momento destrutivo, desestruturador [...] Destruição, separação, morte - essas são as mensagens de que são portadores os anjos benjaminianos" (LAGES, 2007, p. 107).

$\mathrm{O}$ anjo de mãos vazias incorpora, também, a impotência do poeta diante do contexto social marcado pelo sofrimento. Em 1962, o mundo experimentava a tensão da Guerra Fria, assombrado por um iminente crescimento do comunismo. O Brasil alimentava esperança de transformação social, respirava a alegria da conquista da Copa e o requinte da Bossa Nova. Por outro lado, crescia o recrudescimento do autoritarismo e da polarização do jogo político. É o momento em que o poeta tem que ouvir muitas vozes e se perguntar se caminha em boa direção, porque "reminiscências" e "afetos" parecem não bastar à poesia: "Acaso não fui cúmplice dos meus? / Desses vindos da noite e turbados / Com seus próprios destinos?", escreve no Canto Terceiro (HILST, 2002, p. 121). Já no Canto Quinto, a angústia da impotência é sentenciada: "Eu nem soube falar do amor nos homens" (HILST, 2002, p. 121). Antes de escrever os "Poemas

Revista TextoPoético | ISSN: 1808-5385 | Vol. 21 (2o sem-2016) - p. 62. 
aos homens do nosso tempo", de Júbilo, memória, noviciado da paixão (1995), Hilda Hilst já anuncia nos Sete cantos do poeta para o anjo a cumplicidade da poesia com o sofrimento do poeta em face dos momentos de incerteza e sacrifícios pessoais. Assim é que a imagem do sangue colore o Canto Primeiro, situando o poeta em meio a "inocências" e magias verbais, colocando-o apenas como testemunha da História: "Se algum irmão de sangue (de poesia) / Mago de duplas cores no seu manto / Testemunhou seu anjo em muitos cantos / Eu, de alma tão sofrida de inocências / O meu não cantaria?" (HILST, 2002, p. 119). Mas seu manto de duplas cores não deixa a noite fechar-se sobre si mesma.

Hilda Hilst foi leitora de Rainer Maria Rilke. Dora Ferreira da Silva não só traduziu esse poeta como também escreveu sobre ele. Passamos a alguns pontos, levantados pela tradutora-ensaísta, que podem ser entrevistos na poesia de Hilda Hilst. No último número da Cavalo Azul (primavera de 1989), no ensaio "Sobre $O$ livro de horas", Dora assinala que esta obra, escrita entre 1899 e 1906, prende-se à tradição da poesia mística alemã de Echart, Tauler, Angelus Silesius, que "é de uma mística extrovertida, de busca das marcas de Deus no sensível, vivendo a totalidade de suas metamorfoses" (SILVA, 1989, p. 3). Segundo Mestre Echart, "Toda a criação está plena de Deus e é como um Livro", ao que Dora complementa: "A natureza seria um livro cifrado e Deus se manifestaria na vida cósmica, na mobilidade do universo múltiplo e mutável" (SILVA, 1989, p. 3); "aprender a linguagem da terra, a perda da identidade humana, o obscurecimento do que há de divino em todo homem, temas de $O$ livro de horas, é 'a culpa coletiva de hoje e de sempre" (SILVA, 1989, p. 7). Ainda segundo Dora, Rilke "abrigou em sua alma o tempo e o eterno"

Revista TextoPoético | ISSN: 1808-5385 | Vol. 21 (2o sem-2016) - p. 63. 
(SILVA, 1989, p. 7). Talvez o leitor de Hilst reconheça esses versos de Rilke: "Que farás, meu Deus, quando eu morrer? [...] Sou tua roupagem, teu ofício/ e sem mim perderás o teu sentido. [...] Que farás, meu Deus? Eu tenho medo" (SILVA, 1989, p. 4).

Dora Ferreira da Silva foi uma das mais celebradas tradutoras das Elegias de Duíno, arrematando o trabalho com uma análise de cada uma das dez elegias. O tema do Anjo é o mais estudado. Segundo Dora, o anjo representa uma realidade espiritual e superior, uma plenitude que não podemos suportar. Por meio dele é que se vê o desamparo da existência humana. O Anjo terrível de Rilke vai da impossibilidade à aceitação: reduzir a vida das coisas ao espírito e aceitar a morte (SILVA, 1972, p. 65-66). Na primeira elegia, "Os Anjos (dizem) muitas vezes não sabem se caminham entre vivos ou mortos" (SILVA, 1972, p. 67). O Anjo está além do visível. Enquanto o homem é dissipador do próprio ser, o Anjo é símbolo de eternidade. O homem é desfalecente e está cada vez mais afastado do divino. Contudo, alguma coisa feita pelo homem se aproxima do Anjo, como é o caso das grandes criações artísticas (SILVA, 1972, p. 68-69). Por fim, Dora ressalta a conjunção dos opostos na vibrante poesia de Rilke, que pensa a atividade poética na esfera do sagrado, colocando o poeta como o "salvador das coisas torturadas", ainda que isso the custe a vida. Os Sete cantos do poeta para o anjo caminham nessa direção.

\section{Sete cantos: palavra e criação}

Como um fazer divino e prenhe de mistério, a escrita poética transita entre as esferas do terreno e do sagrado, as quais se Revista TextoPoético | ISSN: 1808-5385 | Vol. 21 (2o sem-2016) - p. 64. 
entrelaçam quando o cantar de versos recupera a epifania do dom arquetípico do homem em se ligar às estruturas psicológicas inconscientes. Mas a inspiração poética se mostra como fonte de inquietude e indagação ainda na atualidade. $\mathrm{O}$ que traz o Anjo da poesia? Como o poeta se coloca perante o exercício árduo da criação? Seria o alcance de versos e estrofes um ofício que se inebria de mistérios alquímicos?

Sete cantos do poeta para o anjo, originalmente publicada em 1962 pela Editora Massao Ohno, com ilustrações de Wesley Duke Lee e prefácio de Dora Ferreira da Silva, é uma obra poética que demonstra o quão dedicada, conflituosa e árdua é a concepção de versos, cujos sons e imagens refletem como se dá a inspiração e a criatividade do poeta diante das palavras. Esse livro é uma declaração da constante reflexão da poeta sobre seu ofício, caracterizado como um gesto sublime e sacrificial.

Essa obra foi novamente publicada pela Editora Globo no ano de 2002, em uma coletânea denominada Exercícios, sob a organização e plano de edição de Alcir Pécora. A edição reuniu outras cinco obras poéticas de Hilda Hilst que se aproximam pela cronologia, pela veia criacional, pela raridade das edições anteriores e pela similitude de identificação da poeta na inspiração de seus primeiros versos. São livros publicados por editoras variadas no intervalo de 1959 a 1967.

A fase inicial da produção lírica hilstiana desvela que, com outras obras líricas, a poeta revisita os gêneros poéticos fundantes de estruturas variadas, como as baladas, as odes, as elegias, as trovas, os sonetos e os cantos. Esses gêneros são, acima de tudo, modificados em suas estruturas rítmicas e sonoras.

Revista TextoPoético | ISSN: 1808-5385 | Vol. 21 (2o sem-2016) - p. 65. 
O canto se circunscreve na poesia lírica em estreito vínculo com a música. Rimas e repetições de sons (aliterações e assonâncias) são constantes e as imagens presentificam-se como símbolos de unidades atemporais e existenciais. Resguardando a sugestão musical do título, "Cantos", Hilda Hilst constrói versos com variados recursos musicais, como rimas, aliterações e assonâncias. Em Sete cantos, há predominância de uma atitude de súplica do sujeito com um outro, a quem se destina o canto, o Anjo. O eu identifica-se com o poeta e dirige-se ao Anjo para descobrir como se alcança a realização do canto, que seja sagrado e profano, sublime e terrível, trágico e mágico.

\section{Canto Primeiro}

Se algum irmão de sangue (de poesia)

Mago de duplas cores no seu manto

Testemunhou seu anjo em muitos cantos

$\mathrm{Eu}$, de alma tão sofrida de inocências

O meu não cantaria?

E antes deste amor

Que passeio entre sombras!

Tantas luas ausentes

E veladas fontes.

Que asperezas de tato descobri

Nas coisas de contexto delicado.

Andei

Em direção oposta aos grandes ventos.

Nos pássaros mais altos, meu olhar

De novo incandescia. Ah, fui sempre

A das visões tardias!

Desde sempre caminho entre dois mundos

Revista TextoPoético | ISSN: 1808-5385 | Vol. 21 (2o sem-2016) - p. 66. 
Mas a tua face é aquela onde me via Onde me sei agora desdobrada. (HILST, 2002, p. 119).

Assim como no mito de Orfeu, aqui o eu é como um ser mítico que tem na poesia a possibilidade de sua continuidade diante do caos, ou seja, a possibilidade de permanência no tempo por meio do canto da poesia. Para tanto, a inspiração poética e a harmonia entre sons e palavras são necessárias nesse trânsito rumo à eternidade. Enquanto Orfeu confia a inspiração à sua lira e à sua origem divina, o eu lírico na referida obra também busca a harmonia para seus versos na esfera do sagrado, ou seja, na imagem do Anjo, aquele com quem dialoga, aquele a quem tece elogios e encantamentos a fim de que, desse Anjo, surjam as palavras sagradas, reveladoras do mistério do existir. Mas esse Anjo vem de mãos vazias, e sua canção não é ouvida, suas notas são ininteligíveis.

Dessa forma, o Anjo irrompe como símbolo das tensões imanentes ao ato criador. Ana Maria Lisboa de Mello, em seu livro Poesia e imaginário (2002), é enfática quanto ao símbolo na poesia: "As expressões simbólicas têm múltiplos sentidos, são multívocas e, por isso, implicam a mesma dimensão da interpretação, na medida em que esta consiste em decifrar o sentido oculto no aparente" (MELLO, 2002, p. 20). E ainda: "Na escrita literária, o imaginário é o lugar de reconciliação entre angústia e desejo, carência e seu preenchimento, sentimento de finitude e possibilidade de regeneração, medo da ameaça externa e recolhimento apaziguador [...]" (MELLO, 2002, p. 21). É nesse sentido, numa perspectiva conciliadora, que pode ser compreendido o Anjo dos Sete cantos do poeta para o anjo.

Revista TextoPoético | ISSN: 1808-5385 | Vol. 21 (2o sem-2016) - p. 67. 
Já no Canto Primeiro, o eu se aproxima de toda uma irmandade poética, a começar por Orfeu, estabelecendo com eles uma identidade, uma proximidade tão intensa como a de irmãos. Poetas e Orfeu fundamentam-se na mesma origem, a busca pela memória, pelo existir e pelo criar a partir da inspiração. Ambos eufemizam o tempo e sua perenidade por meio do canto e da poesia. A imagem "passeio entre sombras" resgata as mesmas sombras perpassadas por Orfeu no mundo inferior, os momentos obscuros que cercam o artista no limiar da criação.

Em versos seguintes, o eu canta: "Que asperezas de tato descobri / Nas coisas de contexto delicado. / Andei // Em direção oposta aos grandes ventos". No delicado, o poeta descobre asperezas e não raro substitui a direção fácil por um caminho tortuoso. $\mathrm{O}$ psiquismo conhece mais da sombra do que da claridade; é do inconsciente que brotam os símbolos mensageiros de realidades que não conhecemos. É na sombra que a luz vai brilhar. O verso "E antes deste amor" pressupõe um estado atual - o presente do eu-lírico - marcado por um êxtase em que bem e mal se unem na edificação do poema, o "dizer de bronze" que o poeta celebra e em que se imola. Esse movimento oposto aos "grandes ventos" manifesta-se nos sete cantos. Ainda no último, o Anjo transfigurará treva em resplandescência.

Nos versos do Canto Primeiro, o eu tem no canto a via de similitude com o Anjo, com recorrência a aspectos antitéticos, que fundam os sentidos e os elementos da natureza. Ao iniciar o canto com uma hipótese, expressa pela conjunção se, o eu canta a possibilidade de assimilação do canto sagrado da poesia como um testemunho, pois o Anjo se perfaz pelo gesto de cantar. Entretanto, esse canto torna-se realidade na esfera do sangue, da irmandade do

Revista TextoPoético | ISSN: 1808-5385 | Vol. 21 (2o sem-2016) - p. 68. 
eu com um outro interdito, que, por sua vez, é irmão, "irmão de sangue (de poesia)", não na esfera da inocência da alma do eu.

$\mathrm{O}$ Anjo não testemunha o canto do eu, mas coexiste a possibilidade dos "muitos cantos" terem sido testemunhados pelo "irmão de sangue (de poesia)", como indicativo da essência do eu, "de alma tão sofrida de inocências", que indaga o testemunho do canto do seu anjo ser inerente à esfera da corporeidade do "irmão de sangue (de poesia)". As aproximações sonoras de "sangue", "manto", "canto" e "anjo" formam um tecido denso em que a nódoa do sangue se espalha por todos os versos.

Na segunda estrofe, o canto é antecedido por "luas ausentes", "veladas fontes", revelando, ainda uma vez, que a carência e a falta são necessárias à poesia. Observa-se a presença do som $/ 0 /$, sugestivo de escuridão, um som que coexiste com /a/, mas em proeminência menor: "amor", "passeio", "sombras", "fontes", "coisas", "contexto", "delicado". O ruído é um som sentido na imagem "asperezas", pois o $/ \mathrm{r} /$ assoma-se com o sibilar do $/ \mathrm{s} / \mathrm{e}$ provoca no leitor a intensidade do sentido do toque do eu em busca do canto do anjo. A imagem "sombra" é prenhe da ausência da iluminação divina que deveria sugerir o Anjo, e contrapõe-se a "duplas cores no seu manto", verso da primeira estrofe. Sendo assim, o eu partilha de uma andança rumo ao alcance da luz da poesia, mas é um tatear que descobriu "asperezas de tato", ainda que se devam à delicadeza do cantar, das "coisas de contexto delicado".

Os sentidos conjugam-se na terceira estrofe, o tato e o olhar, sob a égide da elevação, por meio da busca pelo elemento ar. Cantar os sentidos faz com que o eu participe da contemplação do canto do Anjo. A oposição alma e corpo intensifica-se na terceira estrofe: "Desde sempre caminho entre dois mundos". Mas a busca do olhar

Revista TextoPoético | ISSN: 1808-5385 | Vol. 21 (2o sem-2016) - p. 69. 
do eu, rumo aos "pássaros mais altos", traz a contemplação do divino no tão almejado testemunho do canto de seu Anjo, uma contemplação invadida pela luz: "meu olhar / De novo incandescia".

Nota-se que essa terceira estrofe contempla o antagonismo da vogal /a/, aberta e relativa às alturas, ao fechamento e à escuridão de /o/, em imagens que abarcam ambas, imagens que participam, face a face, da convivência do eu com uma duplicidade conflituosa, o claro e o escuro, o sublime e o terreno: "oposta", "pássaros", "altos", "olhar" e "caminho".

Quando se assume desde sempre em "visões tardias", o eu resguarda na atemporalidade a procura pelo canto de seu Anjo, um canto revelador da face desse anjo, uma face que coexiste com o eu: "Onde me sei agora desdobrada". O Anjo, nessa quarta estrofe, ao ser buscado pelo eu, com ele se presentifica, não em canto, mas em essência e consciência de desdobramento, entre o profano e o sagrado, entre a presença e a ausência, um desdobramento que compartilha, mais uma vez, a sonoridade ambígua de /a/ e /o/, na imagem "desdobrada". Os versos da penúltima estrofe reafirmam o permanente conflito lírico entre sofrimento e sublimação, como se forma e fundo se estruturassem do baixo ao elevado.

O Canto Segundo inicia-se com a mesma conjunção do Canto Primeiro, se. É uma maneira de o eu anunciar a presença do Anjo para o fazer poético. Lágrimas, pedras, solidão e madrugadas compõem o hibridismo do canto, que é forma perecível. Só nessa contradição o poema ajusta-se. As lágrimas levam ao encanto. Um ser diluído, de forma perecível, que experimentou as lágrimas, a solidão, o petrificar-se. As imagens pedra e sal remetem ao olhar profano, aquele que penalizou Orfeu e a mulher de Ló. Os dedos

Revista TextoPoético | ISSN: 1808-5385 | Vol. 21 (2o sem-2016) - p. 70. 
lunares completam o quadro de dissolvência. Sem o Anjo, o eulírico nada agarra, nada estrutura.

A possibilidade da anunciação do Anjo pelo eu faz com que haja uma unidade entre eles pautada pela interlocução eu-anjo, uma interlocução permeada pela metalinguagem. O Anjo é pronunciado e, segundo o eu, participa dessa unidade com encantamento: "te encantares do meu canto". Nesse canto, o eu é detentor da habilidade de cantar, usa-a como artifício para que o Anjo dele se aproxime:

[...]

Se te anuncio lágrimas e haveres

É para te encantares do meu canto.

Um tempo me guardei

Tempo de dor aquele

Onde o amor foi mar de muitas águas.

[...]

(HILST, 2002, p. 120).

$\mathrm{Na}$ primeira estrofe, o fazer poético confunde-se com o devotamento da descoberta da poesia, cuja criação se liga ao fato de o poeta se guardar, em dor e com amor, rumo a um árduo gesto: "me guardei", "Tempo de dor aquele".

"Se te anuncio" e "Se te anuncio ainda" questionam, antes de tudo, o porquê do cantar. Se, por um lado, o fato de ter sido talhada em pedra evoca indiferença $\mathrm{e}$ frieza, por outro, lança o eu à eternidade. Mas sua existência foi consumida e fez com que sua forma fosse perecível. Mais uma vez, a referência à sinestesia perfaz-se na metalinguagem: "Estes dedos lunares, estas mãos". A forma do eu talha-se na eternidade e na presença da lua, participante da natureza e astro simbólico da feminilidade. No último verso, a assonância das vogais e a aliteração do /t/ sugere o mistério que envolve a procura pela poesia, em "Tudo o que não foi tocado em ti".

Revista TextoPoético | ISSN: 1808-5385 | Vol. 21 (2o sem-2016) - p. 71. 
A terceira estrofe problematiza o decoro do poeta em consideração ao ritual de entrega ao canto, se em "renúncia", "humildade", "íntegra" ou "sozinha". O fazer desses cantos envolve "ressurreição", "anteprantos" e "alegrias inteiras". A sonoridade dessa estrofe transita de consoantes sibilantes às ruidosas e nasais, pela repetição sonora aliterada, /s/, /r/ e /n/: "Me", "queres", "em", "renúncia", "humildade", "íntegra", "sozinha", "nestes", "cantos", "ressurreição", "anteprantos", "alegrias", "inteiras", "muitas", "madrugadas", "sós", "confessei" e "soturna". Além disso, o canto ao Anjo, ecoado pelo eu, vincula-se ao devotamento e à confissão. Eis, portanto, um canto sagrado e dedicado, um canto que reflete a subjetividade e a interioridade do eu: "E muitas madrugadas / A sós me confessei". Estar em vigília e o envolvimento com confissões preenche a subjetividade do eu com os mistérios da inspiração poética, que traz consigo a feminilidade lunar: "Àquela irmã soturna e mais amada". Logo, se o fazer poético envolve condicionamento, também é contaminado por amor, envolvimento e mistério.

A estrofe final do Canto Segundo sinaliza, mais uma vez, o sinestésico por meio da visão e do tato: "Vi quase tudo. E quase tudo andei”. Eis uma alusão à procura do canto mais adequado para a presença do Anjo. A metalinguagem, nesse sentido, perfaz-se pela andança, pela tentativa e pelo exercício das palavras e da inspiração. Nessa estrofe, devido ao fato de ela ser isolada das demais e cantada em verso único e ainda ser uma estrofe em que coexiste a repetição de vogais abertas e fechadas, /a/ e /o/, identificamos que a entrega do eu ao ofício de versos é prenhe tanto da existência terrena quanto da sagrada: "quase", "tudo" e "andei". O "quase" assinala a dimensão humana, incompleta e insuficiente do poeta.

Revista TextoPoético | ISSN: 1808-5385 | Vol. 21 (2o sem-2016) - p. 72. 
O Canto Terceiro é mais um traço do devotamento do eu lírico ao anjo e à revelação poética que nele existe. O poeta estende-se às coisas, ao homem, ainda que seu "ouvir" sejam "ramas frágeis". A fusão cósmica é experimentada pela poesia, campo em que o poeta se faz demiurgo. Era cúmplice, mas sem conhecer a transcendência que redime a carne. Nessa experiência sem o angélico, tudo é terrível engano.

Eis um canto que retrata a tessitura poética, uma tessitura que se imbrica na existência do poeta, do anjo e da humanidade. Destino, carne, devotamento e sacrifício vinculam-se lado a lado em uma habilidade ancestral e profunda, inebriada do sagrado e do mistério da linguagem, de como o tecer pode ligar-se tanto ao plano terreno quanto ao plano divino.

Em cinco estrofes, o Canto Terceiro reflete a maneira como o eu lírico associa-se ao cosmos. No primeiro verso, o advérbio "largamente" atribui ao verbo "amei" a intensidade do vínculo do eu com a imagem "criaturas". Mais uma vez, o eu assimila-se a sinestesias, apontando "Os ouvidos se abriam" e "Meus ouvidos" como via corpórea de alcance do sagrado, e não perde de vista a natureza, pela imagem "Ramas frágeis". A repetição de sons nasais com ruidosos remete ao acalento do amor e do gesto de ouvir: "largamente", "amei", "criaturas", "os", "ouvidos", "se", "abriam", "Ramas", "frágeis", "Meus", "aceitando" e "ternuras".

Esse canto retrata o terreno, anterior à experiência do eu com a sacralidade terrível do Anjo. Quando o eu parte das experiências terrenas, rememoriza elementos da humanidade: "Pactos, adolescências, heroísmos". São imagens que contam ao eu memórias e recuperam a essência anterior da humanidade. Representam vivências de coragem e vínculo do eu com o terreno e

Revista TextoPoético | ISSN: 1808-5385 | Vol. 21 (2o sem-2016) - p. 73. 
suas memórias, um vínculo necessário para a tessitura de versos, que é árdua e delicada, mas logo se expande pela eternidade: "(Tessitura franzina / Se estendendo sobre a pele mais fina)".

A sinestesia coloca-se nesses dois versos, pois o gesto de construir versos mistura a palavra com o próprio existir do eu; é uma habilidade que se expande diante da pele do eu, cujo tato é o tato dos versos. Assim, viver e cantar fundem-se, como se o canto do eu para o Anjo fosse um ato sacralizado pelo fazer poético, que subleva a condição terrena desse poeta rumo a uma totalidade. A sonoridade desses versos, dispostos isoladamente dos demais pelo recurso gráfico de parênteses, que provoca no leitor o efeito de destaque e caracterização da tessitura de materialidades, dá-se, ainda, pelo coexistir de sons nasais com sibilantes.

Nos três versos seguintes, mais uma vez, o hipotético é cantado: "Acaso", quando o eu questiona a cumplicidade com o terreno e com o destino dos homens, sujeitos ao tempo e à finitude. Nesse momento, a matéria da poesia é a condição humana.

Já a penúltima estrofe do Canto Terceiro indica que o destino, para o eu, o distanciou da sacralidade propiciada pelos cantos amparados pelo Anjo. A existência desse anjo teria sido negada pela associação do eu a elementos terrenos, relativos a destino, temporalidade, caos e finitude. O que nos remete a essa interpretação é a imagem "Que terrível engano antes de ti!". O tempo sagrado, dedicado ao Anjo foi substituído por "vigílias inúteis e pobrezas", ocorridas "Na carne!", no sentido de tessitura de fios de palavras e de desamparo humano. Antes de cantar o Anjo, o eu transitava, sozinho, por experiências da carne, terrenas e temporais:

Revista TextoPoético | ISSN: 1808-5385 | Vol. 21 (2o sem-2016) - p. 74. 


\section{[...]}

Que terrível engano antes de ti!

E vigílias inúteis e pobrezas

E punições maiores, tais cilícios

Na carne! Tramas, tramas.

[...]

(HILST, 2002, p. 121).

Assim, no último verso, na última estrofe, das demais isolada, "Que era feito de ti? Em mim, não eras", o eu atribui ao Anjo, em direta interlocução, quão árdua foi a experiência da ausência desse anjo, como essa ausência se configurou não somente em dor e sofrimento. Houve, sobretudo, um sacrifício que inclui o corpo, "Na carne!", uma imagem cujo impacto se intensifica com o ponto de exclamação. Analisamos essa pontuação como intensificadora do lamento do eu por não ter cantado o Anjo em um tempo anterior. Ausente, o anjo não testemunhou seu amor pelos homens nem seu suplício diante da tessitura poética.

O Canto Quarto traz o poeta em face da perplexidade do poder que the foi concedido, messiânico, poder este não exercido sem a certeza da impotência e um demérito autoimputado. Deve falar pelos outros em um mundo de constante transformação e de sofrimento. O poeta deve apreender essa matéria proteica, "e carregava atônita meu gesto", cuja alquimia acompanha sua própria poesia, de bronze e prata. A penumbra sugere o estágio demorado e necessário da Nigredo, as palavras e seu lento depurar-se e transmutar-se em metal nobre, cujo melhor alcance no poema em questão seria a "prata".

Como os alquimistas espirituais, buscando incessantemente a transformação dos metais vis em metais nobres, no fundo buscando

Revista TextoPoético | ISSN: 1808-5385 | Vol. 21 (2o sem-2016) - p. 75. 
uma analogia com a existência humana, seu percurso a um estágio elevado, o poeta faz de sua poesia o atanor em que mistura palavras, ideias, sentimentos, operando um texto que sirva de iluminação para o homem, cuja verdade só será dada no plano do mistério. Na constante transmutação, o poeta está no encalço da completude perdida. Esta só será restabelecida integrando as forças opostas (a alquimia chega à androginia, força maior), assim como o canto chega à sua plenitude pela falta, pelo sacrifício.

A linguagem só pode ser a simbólica, que junta ao que conhecemos um mistério que jamais será revelado. Entre vida e morte, conhecimento e mistério, presença e ausência, linguagem e símbolo, o poeta supera as antinomias, promove a coincidentia oppositorum, tornando inviável a eleição de um Anjo que conheça somente a luz ou somente as trevas. Mas o poeta transforma a si também, uma vez que o poema é uma ferramenta mágica para o alcance desse sagrado, que é ao mesmo tempo fascinans e tremendum. O fazer poético é um fazer misterioso, mas pleno de magia, pois é um exercício do sagrado: encanta, perturba e desconcerta o eu.

Nos versos "E carregava atônita meu gesto / Porque dizia coisas que nem sei", o eu, além de referir-se a si em feminino, remete-se ao desconhecimento da origem de suas palavras; logo, as mesmas seriam oriundas de uma esfera sagrada, donde o ato de "carregar" atribui a essas palavras o aspecto de dom. Eis, desse modo, um canto que persiste e tem sua continuidade no tempo, com o verbo no gerúndio, "cantando", tanto através do próprio ato de cantar como também a partir da imagem "reminiscências".

Revista TextoPoético | ISSN: 1808-5385 | Vol. 21 (2o sem-2016) - p. 76. 
$\mathrm{Na}$ segunda estrofe, o eu reitera a presença do Anjo em sua criação poética. É uma estrofe que remete o leitor à elevação pela predominância da assonância de /a/, que sugere a escuta de vozes divinas pelo eu, nesse caso, a voz do anjo: "continuamente", "muitas", "Umas", “água”, “tão", “intensas”, “outras" e "crepusculares". A criação poética não é uma criação isenta, é uma criação que envolve a escuta de "muitas vozes", que perpassa de "intensas" a "crepusculares". Essas imagens possibilitam a presença de elementos misteriosos e alquímicos nas próximas estrofes. Os elementos da natureza polarizam-se entre "fogo" e "água", elementos que regem transformações em tudo aquilo sobre que agem. São vozes, portanto, ambivalentes, cuja ambiguidade coexiste sem que se perca a unidade criacional.

Poesia e alquimia fundem-se na transformação da matéria em busca de uma chave simbólica que espelhe uma definição existencial. Quando o eu rima "ciência" com "alquimia" e com "essência" participa da unidade entre o existir, o definir e o criar. Nesse rumo, molda a criação poética a partir de elementos da natureza, comparando a criação alquímica pelo homem ao ato de operar com as palavras. Sobre a proximidade entre a poesia e a alquimia, retomamos a reflexão de Eliane Robert Moraes. Em $O$ corpo impossivel (2002), poesia e alquimia seguem, de acordo com a autora,

[...] um designio comum em, pelo menos, três níveis: na preocupação de remontar à matéria original do mundo e da linguagem; na operação de transformar as substâncias do universo e do verbo; e no trabalho de interpretação através da grade inesgotável das analogias, chave de todo ato de decifração (MORAES, 2002, p. 77).

Revista TextoPoético | ISSN: 1808-5385 | Vol. 21 (2o sem-2016) - p. 77. 
O primeiro verso da quarta estrofe configura-se como uma máxima ditada pelo Anjo à consciência do eu. É um conceito que foi antecipado pelo emprego gráfico de dois pontos; logo, é um ensinamento a ser destacado no poema. Ser só e, ao mesmo tempo, ser constelar indica que não somente o eu, mas também a humanidade como um todo são reflexos de uma ambiguidade existencial:

$[\ldots]$

O homem é só. Mas constelar na essência.

Seu sangue em ouro se transmuta.

Na pedra ressuscita.

No mercúrio se eleva.

E sua verdade é póstuma e secreta.

$[\ldots]$

(HILST, 2002, p. 122).

O ser só, individual e descontínuo repousa na materialidade da condição humana. Porém a essência criacional e transformadora do homem alça essa individualidade para outra esfera, a esfera da unidade e do alcance do infinito, do atemporal, do sagrado, uma esfera possibilitada pelo fazer poético em conjugação com a inspiração. A sacralidade que envolve a escolha do Anjo pelo eu, dentre tantos outros homens, faz desse eu um foco de constelação, daí a representação da constelação como o eixo orientador de uma unidade em sua essência.

Nos versos seguintes dessa estrofe, elementos alquímicos revelam segredos, elevações, ressuscitações. O transmutar experimentado pela matéria é operado pela poesia. $\mathrm{O}$ eu remete-se a transformações ao se referir à essência do homem: "Seu sangue em ouro se transmuta". De igual modo, o fazer poético é um fazer divino

Revista TextoPoético | ISSN: 1808-5385 | Vol. 21 (2o sem-2016) - p. 78. 
e prenhe de transformações não apenas materiais, mas, sobretudo, subjetivas. Quando em ouro se transmuta o sangue, o homem alça rumo a uma continuidade atemporal.

A inspiração poética, da mesma maneira como a alquímica, engloba modificações, nas palavras e nos elementos. Poesia e alquimia são artes do mistério, revelado a partir do canto do eu que transforma, em versos, "sangue" em "ouro", o que traz à imagem "O homem é só" o alcance de uma totalidade desconhecida: "Mas constelar na essência." A respeito do ouro, fundamental no mistério da operação alquímica, assim nos esclarece Gilbert Durand na obra As estruturas antropológicas do imaginário:

O ouro com que o alquimista sonha é uma substância oculta, secreta, não o vulgar metal, aurum vulgi, mas o ouro filosofal, a pedra maravilhosa, lapis invisibilitatis, alèxi pharmakon, "tinta vermelha", "elixir de vida", "corpo de diamante", "flor de ouro", corpus subtile, etc. Todos os vocábulos dizem incansavelmente que o ouro é justamente o princípio substancial das coisas, a sua essência encarnada (DURAND, 2002, p. 262).

Dessa maneira, o homem e o poeta, quando inebriados pelo êxtase divino, percorrem modificações definitivas que envolvem a natureza e a alquimia. Sobre a alquimia, assim como a poesia, tratase do exercício da dedicação e do debruçar do homem rumo ao desconhecido. É uma ciência que contempla o mistério e a transformação, mas que traz consigo o significado simbólico do homem em embate com sua essência.

As imagens "pedra" e "mercúrio", além de se referirem à alquimia, remetem também aos elementos naturais terra e ar, respectivamente. O estático não é cantado, mas o ressurgir e o elevar, atos relativos a mobilidade e transformações. O último verso dessa

Revista TextoPoético | ISSN: 1808-5385 | Vol. 21 (2o sem-2016) - p. 79. 
estrofe repousa na condição humana, tão secreta como a alquimia, por meio da imagem "verdade". O segredo é a essência do homem, não o fato de o homem ser isolado.

Buscando elementos nobres como na operação alquímica, o eu sabe que não alcançou a depuração necessária: "Ah, vaidade e penumbra no meu canto!". As palavras são feitas de "bronze" e o tecer de versos estrutura-se na imagem "teia de prata". É uma estrofe que, mais uma vez, alude, pela assonância de /a/, ao alto e ao divino, à transformação e à inspiração, que urgem tanto da alquimia quanto da poesia: "Ah", "vaidade", "penumbra", "canto", "essa", "teia", "prata", "mesma" e "espanta".

Magia, encantamento, transformação e descoberta envolvem o fazer poético, mas, ao mesmo tempo que o criar em canto e palavra provoca arrebatamento, descoberta, magia e vaidade, também traz perplexidade e mistério.

Portanto, a assimilação de elementos e de metais transformados pela alquimia nos permite interpretar o canto desse Anjo como um canto que, assim como a alquimia transforma elementos em metais, a inspiração transforma palavras em canto e poesia.

O Canto Quinto é todo de negações afirmadoras da impotência: não soube amar os homens nem a natureza nem fazer poesia. Não soube transmutar o mantra em uma "corda divina". A poesia essencial está ligada ao sofrimento, resulta da impossibilidade do poeta.

Pouco a pouco, o eu se vê em transformação e em similitude com a esfera do sagrado. A fonte que o inspira, paulatinamente, sobressai até o divino e dá-se uma dependência entre o eu e o Anjo. A consciência do eu de sua limitação perante o saber, ao mesmo 
tempo em que assume o devotado amor pelo Anjo, faz com que o eu com ele estabeleça uma unidade criacional.

Na primeira estrofe, o eu sinaliza imagens terrenas: "o amor nos homens", "replantar no que era terra" e "Uma mesma semente.” São imagens plenas na continuidade de aspectos terrenos, cuja impossibilidade é permeada por uma repetição sonora, que nos sugere o tom de refrão e de reforço do sentido: "Nem soube", nos versos primeiro e terceiro. Novamente, os elementos da natureza são cantados, e a terra sobressai-se no poema como uma imagem simbólica de vida e alimento na consciência profana:

Eu nem soube falar do amor nos homens.

(Amor feito de júbilo aparente)

Nem soube replantar no que era terra

Uma mesma semente.

Tive no peito o mantra mais secreto

E não pude vibrá-lo, alento, lira

Corda divina no seu veio certo.

$[\ldots]$

(HILST, 2002, p. 123).

Mesmo com o atributo necessário para o perfazer do canto, o eu não o emite. Teve consigo uma fonte de inspiração, "Tive no peito o mantra mais secreto", que não pôde ser vocalizado, "E não pude vibrá-lo". Dotado de um sagrado instrumento, o mesmo que fora atribuído a Orfeu, "lira", "Corda divina", o eu lírico nele não produz sonoridade, porque estava em experiência terrena, e sua ligação com o divino urgia uma exclusiva dedicação.

$\mathrm{Na}$ segunda estrofe, o eu persiste no reconhecimento de que seus sonhos foram em vão. Mas o Anjo se presentifica: "E súbito me tomas e me ordenas / A solidão mais funda:". Ao sinalizar os dois Revista TextoPoético | ISSN: 1808-5385 | Vol. 21 (2o sem-2016) - p. 81. 
pontos, o eu perfaz a continuidade propiciada pelo anjo. A inspiração dele advém, pois o Anjo tem o poder sobre o fazer poético, mesmo quando de mãos vazias.

$\mathrm{O}$ fato de tomar e ordenar indica uma sublime coexistência entre o Anjo e o eu, pois, fundidos, formam o mistério da inspiração poética. Não mais o eu oscila na transitoriedade, nem na fragmentação. A imagem "solidão", nesse sentido, não é indicativa de o eu estar só, mas nos sugere a entrega do eu ao mergulho a uma subjetividade ainda mais profunda. "Estes cantos agora, alguns poemas". As imagens "cantos" e "poemas" são representativas do dom sagrado que o anjo oferta ao eu, depois de longo sofrimento do homem em sua esfera de materialidade e de efemeridade, condição que só a poesia pode reverter.

No que concerne aos sons, a segunda estrofe é toda construída pela sonoridade de rimas internas: "vão", "solidão", "tão" e "não". O efeito de sentido provocado por tal sonoridade contínua é o de ressoar a ideia de negação e ausência que se aplica ao fazer poético.

$\mathrm{Na}$ última estrofe, o gesto de nomear singulariza e torna o nomeado participante da temporalidade. A necessidade do eu em dar um nome ao Anjo é a de apaziguar-se com o mistério não apenas da poesia, mas, ainda, o mistério da inspiração lírica, a qual gera desconcerto. Eu e Anjo imbricam-se, unem-se e misturam-se em uma junção sagrada que conflui terreno e divino: "Se o teu batismo é o meu e eu só te soube / Quando soube de mim?". Nesse sentido, o dialogar do eu com o Anjo assume o âmbito do diálogo do eu com sua subjetividade. É um solilóquio do eu diante de sua inconsciência, pois a subjetividade do eu é regida pela ordenação e pelas ações inspiradoras do Anjo.

Revista TextoPoético | ISSN: 1808-5385 | Vol. 21 (2o sem-2016) - p. 82. 
Portanto, o ato batismal, na imagem "batismo", inaugura no eu a face do sagrado. Ao recorrer a uma imagem representativa de um sacramento, o eu dialoga com o divino e com a esfera da atemporalidade, mesma esfera da poesia. Nomear é, sobretudo, um ato sagrado, ligado a um pertencimento no universo. Esse "batismo" percorre tanto o Anjo quanto o eu, e a consciência do eu diante do saber desse anjo mistura-se com a sabedoria e a consciência de si. Eu e Anjo, conjugados, são, por conseguinte, a união da inspiração - o divino, o anjo - com o fazer poético - o ofício do eu como poeta, o humano.

No Canto Sexto, o poeta, como o Anjo, também é amaldiçoado. Basta tocar para mudar a fortuna das coisas. Gerado pelo "ódio dos deuses", conhece a elevação e o esquecimento. Desolado, o eu busca o que lhe falta. A inspiração angélica é agora a inspiração da noite, que, profana e misteriosa, invade o inconsciente do eu. Do nojo à depravação são oriundos os versos e inaugura-se um sofrimento, pela busca dos elementos naturais e pela recorrência às memórias. A falta do Anjo e a possibilidade de inspiração atormentam o eu em esquecimento, perda, pranto e perenidade.

$\mathrm{Na}$ primeira estrofe, o eu é abruptamente atingido pelas inexatidões da "noite". O sofrimento e o caos desvelam-se, "As coisas insofridas / Sofridas se faziam". O repouso, nessa primeira estrofe, não sinaliza paz ou descanso, mas a possibilidade de sofrimento intensificado. Nessa estrofe, há a repetição sonora, por duas vezes da palavra "sofridas", mas, na primeira aparição, ela vem seguida do prefixo 'in'. Essa repetição de palavra provoca o efeito de dor e de prolongamento do sofrimento. Já a aliteração /s/ na quarta estrofe indica a lamentação contínua da ausência do Anjo na criatividade do eu.

Revista TextoPoético | ISSN: 1808-5385 | Vol. 21 (2o sem-2016) - p. 83. 
A segunda estrofe canta uma memória comparada às águas primordiais, doadoras da vida. A evocação da água instaura o frescor e a fluidez do devaneio, sensação que logo será dominada pelo pensamento do ódio e do abandono. Mas é um tempo de relaxamento, de possibilidades, como dirá Gaston Bachelard, na obra A água e os sonhos, de "desobjetivação":

A água é também um tipo de destino, não mais apenas o vão destino das imagens fugazes, o vão destino de um sonho que não se acaba, mas um destino essencial que metamorfoseia incessantemente a substância do ser [...] A água, agrupando as imagens, dissolvendo as substâncias, ajuda a imaginação em sua tarefa de desobjetivação, em sua tarefa de assimilação (BACHELARD, 1997, p. 6, 13).

A próxima estrofe isola-se das demais. Sinaliza um refrão, em único verso, e contempla, simultaneamente, a interlocução - em formato de questionamento - do eu com o Anjo e a consciência de seu distanciamento. $\mathrm{O}$ eu situa-se como abandonado, pois não é fonte nem sequer de sonho por parte do anjo, e pontua-se, nesse sentido, como solilóquio e dialoga consigo mesmo, tamanho o caos provocado pelo rompimento com o Anjo.

Em seguida, a espera por "um tempo que viria" consola o aguardar e permite ao eu uma tranquilidade: "Deitei-me". As "visões" oriundas desse repouso não são desordenadas, mas obedecem a uma continuidade e trazem um reflexo de sagrado, são cíclicas: "um ciclo de visões". Essas visões, reveladas, equiparam o eu ao tempo e, mesmo no "ódio dos deuses", o eu é lembrado, pois nele se reconhece integrado.

$\mathrm{Na}$ estrofe a seguir, mesmo tendo alçado voo e se assimilado à ave e ao elemento aéreo, pela participação das alturas, o eu mantémse no esquecimento, pois não traz mais consigo a inspiração poética Revista TextoPoético | ISSN: 1808-5385 | Vol. 21 (2o sem-2016) - p. 84. 
ditada pelo Anjo. É um voo, alto, mas não se trata de um voo angélico, as asas que rodeiam o eu não são as do anjo, mas de ave. Não há, nessa imagem, portanto, predominância do sagrado ou profano, o que prevalece é a referência ao plano terreno, no movimento de subida e descida.

A penúltima estrofe fala de ausência de voo, fixando o cantar terreno num plano dessacralizado: "E porque paz e voo me faltavam". O eu identifica-se como isolado e fragmentado da inspiração. A falta e o destino são aqui cantados como necessidades primeiras do eu em busca da inspiração. Para o eu, o desejo pelo divino permeado pelo Anjo mistura-se a uma entrega fremente, que contempla "perdas destinadas":

$[\ldots]$

E porque paz e voo me faltavam

Eu desejei perder-me mais e tanto

Quanto fossem as perdas destinadas

Àqueles incapazes de algum pranto.

[...]

(HILST, 2002, p. 124).

É um perder-se intenso, mas simbólico da condição caótica do eu cindido da sacralidade da presença do anjo. Nesse sentido, o voo almejado pelo eu não é o de asas ou de aves, mas o voo do Anjo. Somente esse voo lançaria o eu à memória e romperia com o esquecimento, condição que ao eu fora submetida.

"Perenidade e vida" são experiências de quem compartilha do angélico. $\mathrm{O}$ eu finaliza o canto com mais uma pergunta, dirigida ao Anjo e seus atributos: "Onde estavas?" O fato de ser cantada em único verso faz da última estrofe a invocação de um dialogismo eu

Revista TextoPoético | ISSN: 1808-5385 | Vol. 21 (2o sem-2016) - p. 85. 
e anjo. Para o eu, portanto, a eternidade e o decorrer diante do tempo só são possibilitados pela inspiração oriunda do Anjo.

No Canto Sétimo, a poesia consome-se em sua própria existência. Para que ela continue fazendo sentido, é preciso que o Anjo não transfigure o verso, ainda que esteja com sua "dulcíssima presença". O verbo no pretérito, "foi", indica a transfiguração sofrida, mas poesia e mundo hão de conservar a oposição. Afinal, o Anjo é um "prisma solarizado" e de "Alta noite".

A agonia do eu diante da falta do anjo, bem como a escuridão pelo eu percorrida, sem a inspiração para o cantar de versos, e a poesia como arte transcendente, cuja presença se equipara à presença do anjo no eu, são aspectos que transitam nesses versos do último canto. Então, presença e ausência, sagrado e profano, dor e alegria, voo e queda dão conta de um poeta reconciliado com um anjo que se anuncia de mãos vazias.

Na primeira estrofe, a morte do eu deve-se ao ocultamento do anjo. Essa morte é sinalizada por uma marca, a imagem "chaga", símbolo de sofrimento e transitoriedade entre o mundo terreno e o sagrado. É uma ferida intensa na carne; logo, essa imagem reporta o eu ao campo do terreno, pois o Anjo está ausente, conforme o eu assumira no canto, "Te ocultaste". Por outro lado, funciona como estigma, uma manifestação de Deus em seus eleitos.

Há um enjambement entre o último verso da primeira estrofe e o primeiro verso da segunda. Essa segunda estrofe isola-se das demais e exibe um teor de invocação de sofrimento do eu. A imagem "dorso calcinado" intensifica o sofrimento do eu pela ausência do Anjo. É um sofrimento agonizante, digno de morte e ruptura com o sagrado, ou, o contrário, de manifestação intensa dele, à revelia do

Revista TextoPoético | ISSN: 1808-5385 | Vol. 21 (2o sem-2016) - p. 86. 
desejo humano, como se o eu tivesse se devotado tanto na procura pela sacralidade do anjo, que acabou por se culpar e, por isso, o gesto sacrificial de ter o dorso queimado, mas restou assinalado pela presença divina.

$\mathrm{Na}$ estrofe subsequente, trevas, noite e claridade coexistem. A treva leva ao delírio, e o excesso de luz ofusca a percepção. Portanto, o anjo perturba pela presença e pela ausência. A sinestesia do olhar é cantada a partir da imagem "pálpebras em brasa", acentuando os riscos da clarividência. Ao mesmo tempo em que o eu almeja a claridade da revelação da inspiração por meio do anjo, tem o impedimento da visão por meio do fogo.

A quarta estrofe é simbólica dessa ausência. A alma do eu encontra-se perdida, "minha alma toda se perdia". O eu aproxima-se cada vez mais do terreno e dos elementos naturais: "E uma vida terrena começava". Nesse sentido, o eu assimila-se às cinzas e nelas habita. A respeito de cinzas, identificamos nessa imagem a presença do elemento fogo, que, além de trazer modificações, promove renascimentos e superações, como em Fênix, figura mitológica que das cinzas renasce e se fortalece.

Nesse rumo de transformações abruptas permeadas pelo elemento fogo na imagem "cinza", ao final da quarta estrofe, o Anjo passa a habitar nessa casa de cinza, que é a casa perecível do poeta.

Sendo assim, na quinta estrofe, eu e anjo voltam a estabelecer divina comunhão. "Anjo, asa", em enjambement com "Mão poderosa sobre a minha mão / Que o verso nunca mais transfigurava" simboliza uma junção definitiva, cuja ruptura de outrora fora transformada por intermédio do elemento fogo espiritual -, que purificou o terreno ao reduzi-lo a cinza. $\mathrm{O}$ verso

Revista TextoPoético | ISSN: 1808-5385 | Vol. 21 (2o sem-2016) - p. 87. 
agora transfigura-se em palavras e cantos, e o anjo, novamente, passa a ter poder sobre a inspiração do eu. Sobre a sonoridade, no Canto Sétimo o som /asa/ repete-se três vezes, em estrofes distintas. Trata-se de uma rima cujo efeito sonoro intensifica a presença da imagem "asa" no poema.

Desse modo, "brasa", "casa" e "asa" assimilam a prevalência do Anjo no canto, sendo que "brasa" antecipa o que se fará presente na inspiração do eu, o Anjo. Para Gaston Bachelard em $O$ ar e os sonhos (2001), a asa é um atributo associado ao divino desde Platão, em Fedro. Há um vínculo entre asa e transcendência: “'A força da asa consiste, por natureza, em poder elevar e conduzir o que é pesado para as alturas onde habita a raça dos deuses. De todas as coisas atinentes ao corpo, são as asas as que mais participam do que é divino"' (BACHELARD, 2001, p. 68).

Após tantas ausências alimentadoras do canto, na presença do Anjo o eu inspira-se: "Mão poderosa sobre a minha mão" e "Dulcíssima presença" a imagem da "mão" é duplamente evocadora do poder divino e humano, no caso, da inspiração e da atividade do poeta:

$[\ldots]$

Anjo, asa

Mão poderosa sobre a minha mão

Que o verso nunca mais transfigurava.

Prisma solarizado

Transcendência primeira

Dulcíssima presença:
Alta noite
O que foi treva em mim
Em ti resplandecia.
(HILST, 2002, p. 125).

Revista TextoPoético | ISSN: 1808-5385 | Vol. 21 (2o sem-2016) - p. 88. 
A seguir, as três estrofes finais destacam-se das demais e constituem-se de apenas um verso cada. A antepenúltima, a penúltima e a última estrofes formam entre si mais um enjambement, sugestivo da continuidade e do prolongamento da noite vivida pelo eu, uma noite de treva, de mistério e de ausência de inspiração, mas uma noite que se conjugou com a revelação do Anjo inspirador, pleno em luz: "Alta noite // O que foi treva em mim // Em ti resplandecia.”. À treva, à noite, ao mistério e à escuridão assoma-se a iluminação e, nesse caminho, tornam-se complementares o eu e o anjo, o terreno e o sagrado, o escuro e a luz, o desconhecimento e a inspiração.

\section{De mãos vazias}

Aos Sete cantos do poeta para o anjo, aplica-se o que Dora Ferreira da Silva intuiu a propósito da décima e última elegia de Rilke: opera a síntese da lamentação e do louvor. Rilke diz: "Que meu rosto se ilumine sob o pranto! Que a obscura lágrima floresça!" (SILVA, 1972, p. 91). O que se tem, então, é a afirmação "jubilosa e vibrante" da dor. A poeta e tradutora completa: "Esse canto transfigurado que ascenderá até os Anjos aprovadores não é a expressão da simples alegria que brota dos aspectos amáveis da existência, mas é o poderoso canto fecundado pelas 'noites de aflição"” (SILVA, 1972, p. 91). Segundo Dora, as Elegias mostram que só é possível alcançar o real pelo sofrimento, quando Morte e Dor são "As grandes educadoras do homem", sobretudo no que diz respeito à missão poética.

Revista TextoPoético | ISSN: 1808-5385 | Vol. 21 (2o sem-2016) - p. 89. 
Rilke não teme o paradoxo: é no coração frágil do homem, o mais efêmero de todos os seres, que se cumpre a transmutação do finito em infinito, do transitório em eterno; em seu coração a "externalidade" será enfim devolvida ao Absoluto. Como? Através da aceitação plena do terrestre, afirmando apaixonadamente o "aqui e agora", vendo na morte, não o "outro lado", a promessa da transcendência, mas a mais íntima e sagrada inspiração da terra. Nessa imanentização, os opostos coincidem, o finito infinitiza-se, o efềmero se eterniza (SILVA, 1972, p. 89).

$\mathrm{Na}$ mesma linha da coincidentia oppositorum, o canto jubiloso será aquele fecundado pela dor. O poeta paraense Paulo Plínio Abreu, que também traduziu a obra de Rilke, afirma que Elegias de Duíno é um desejo de "restaurar o sentido órfico da poesia" e ultrapassar o sentido estético, numa "tentativa de conseguir uma solução para o próprio problema da existência e a fórmula de conciliação do homem com a vida" (ABREU, 2008, p. 116). Manifestando o teor sagrado que envolve os Sete cantos do poeta para o anjo, cuja sacralidade vem eivada de súplica, dor e vazio, o vocabulário remete a um contexto litúrgico. Termos como "ressurreição", "vigílias", "cilícios", "mago", "carne", "verbo", “júbilo", "visões", “divina", "vi”, "confessei”, "manto”, "alma", "chaga", "terrena", "treva", "caminhei sobre as águas" ecoam nos versos até configurar o poema como uma oferenda, esteticamente pleno, mas sem resposta, como as mãos vazias do Anjo.

À maneira de Rilke, a poesia congrega a morte, é o exercício de conjugar pares antitéticos que atormentam o homem, salvando-o pela palavra, e opera uma transformação de tal sorte que o nada, o inatingível, o obscuro e o incorpóreo sejam aceitos

Revista TextoPoético | ISSN: 1808-5385 | Vol. 21 (2o sem-2016) - p. 90. 
como condição mesma da poesia, o impulso criador. Quando o anjo se afasta, quando a dor se instaura, começa a poesia. Todo o esplendor do angélico é vazado nessa ambiguidade que acompanha a realização poética.

\section{Referências}

ABREU, P. P. Poesia. Belém: EDUFPA, 2008.

BACHELARD, G. O ar e os sonhos. Trad. Antonio de Pádua Danesi. São Paulo: Martins Fontes, 2001.

. A água e os sonhos. Ensaio sobre a imaginação da matéria. Trad. Antonio de Pádua Danesi. São Paulo: Martins Fontes, 1997.

BENJAMIN, W. Magia e técnica, arte e política. Ensaios sobre literatura e história da cultura. São Paulo: Brasiliense, 1985.

DURAND, G. As estruturas antropológicas do imaginário. Trad. Hélder Godinho. São Paulo: Martins Fontes, 2002.

HILST, H. Exercícios. Org. Alcir Pécora. São Paulo: Globo, 2002.

LAGES, S. K. Walter Benjamin - tradução e melancolia. São Paulo: Edusp, 2007.

MELLO, A. M. L. Poesia e imaginário. Porto Alegre: Edipucrs, 2002.

MORAES, E. R. O corpo impossível. São Paulo: Iluminuras, 2002.

SILVA, D. F. da. Comentários. IN: RILKE, R. M. Elegias de Duíno. Tradução e comentários de Dora Ferreira da Silva. São Paulo: Globo, 1972. . Sobre o livro de horas. In: Cavalo Azul, n. 11 e 12. São Paulo: Estúdio Massao Ohno, Primavera de 1989.

. Duas experiências do Angélico (prefácio). In. HILST, Hilda. Sete cantos do poeta para o anjo. São Paulo: Massao Ohno Editor, 1962.

Revista TextoPoético | ISSN: 1808-5385 | Vol. 21 (2o sem-2016) - p. 91. 
WILLER, C. Encarnações da poesia. Jornal de poesia. Disponível em: http://webcache.googleusercontent.com/search?q=cache:http://www

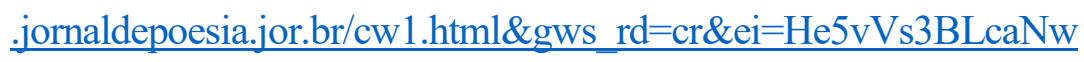
wSAv4m4Bw. Acesso em: 15 dez. 2015.

Aprovado em 21 de Fevereiro de 2016.

Revista TextoPoético | ISSN: 1808-5385 | Vol. 21 (2o sem-2016) - p. 92. 


\section{A AUSÊnCIA do SOM E A PERFORMANCE DO CORPO: \\ CRIAÇÃO DE RITMO NOS POEMAS EM LÍNGUA BRASILEIRA DE SINAIS}

The absence of sound and the body performance: creating rhythm in poems in the brazilian sign language

Nayara Piovesan RIBEIRO

UFMT

nah_piovesan@hotmail.com

Vinícius Carvalho PEREIRA ${ }^{17}$

UFMT

viniciuscarpe@gmail.com

Fábio Vieira de SOUZA JÚNIOR ${ }^{18}$

UFMT

fabiovieirajunior@hotmail.com

RESUMO: Este artigo analisa o poema "Cinco sentidos", tradução para a Língua Brasileira de Sinais feita pelo artista surdo Nelson Pimenta, a partir do poema "Five Senses", originalmente produzido pelo também surdo Paul Scott, na British Sign Language. Nosso objetivo é identificar como se constituem elementos da camada fônica, tais quais o ritmo e a rima, em poemas surdos. Para tanto, revisitamos alguns conceitos de poesia, poema, ritmo e rima, originalmente pensados para línguas orais, a fim de verificar como esses se

${ }^{16}$ Mestranda do Programa de Pós-Graduação em Estudos da Linguagem, na área de concentração em Estudos Literários, da UFMT.

${ }^{17}$ Doutor em Ciência da Literatura pela UFRJ. Docente do Departamento de Letras e do Programa de Pós-Graduação em Estudos da Linguagem, da UFMT.

${ }^{18}$ Mestrando do Programa de Pós-Graduação em Estudos da Linguagem, na área de concentração em Estudos Linguísticos, na UFMT. Docente do Departamento de Letras, da UFMT.

Revista TextoPoético | ISSN: 1808-5385 | Vol. 21 (2o sem-2016) - p. 93. 